\title{
Raising Competitiveness for Tourist Destinations through Information Technologies within the Newest Tourism Action Framework Proposed by the European Commission
}

\author{
Ray F. Iunius ${ }^{1}$, Laura Cismaru ${ }^{2, *}$ and Diana Foris ${ }^{2}$
}

1 École Hôtelière de Lausanne, Route de Cojonnex 18, Lausanne 1000, Switzerland; E-Mail: Ray.IUNIUS@ehl.ch

2 Faculty of Food and Tourism, Transilvania University from Braşov, str. Castelului, nr. 148, 500014 Brașov, Romania; E-Mail: diana.foris@unitbv.ro

* Author to whom correspondence should be addressed; E-Mail: laura.cismaru@unitbv.ro; Tel.: +40-720-289007; Fax: +40-268-472222.

Academic Editor: Andrei Jean Vasile

Received: 28 June 2015 / Accepted: 14 September 2015 / Published: 18 September 2015

\begin{abstract}
Several challenges regarding the European tourism industry were recently identified at EU level which the experts of the European Commission tried to meet, thus formulating several priorities within the newest Tourism Action Framework: Stimulate long-term competitiveness in the European tourism sector, promote the development of sustainable and high-quality tourism, and consolidate the image and promotion of European tourist destinations. Due to the new generational context, information and communications technology ICT and innovation became keywords within the most recent European Tourism Policy. Considering the symbiotic relationship that exists at the European tourism level between sustainable development, innovative ICT solutions, and long-term competitiveness, the decision-makers in European destinations should focus on identifying innovative ways to implement the new Tourism Action Framework adopted by the European Commission, through ICT applications, in order to support long-term competitiveness achievement. Two such authentic proposals are formulated within the present discussion paper: the creation of a decision support system for the management of sustainable European destinations and the development of a trip-planner for quality-sensitive tourists based on an umbrella European certification/labeling system for tourism quality. There is still a fertile field in these areas and, therefore, more innovative ICT tools to support the long-term competitiveness of European tourist destinations can be developed.
\end{abstract}


Keywords: European action framework for tourism; long-term competitiveness; sustainability; innovative ICT tools; tourist destinations

\section{Introduction}

The concept of "tourist destination" is a complex one, all tourist destinations actually being amalgams of products, services, and experiences, with many different stakeholders involved. Buhalis formulated the following definition of the tourist destination: "a defined geographical region which is understood by its visitors as a unique entity, with a political and legislative framework for tourism marketing and planning" [1]. According to Ritchie and Crouch, "the tourist destination is the fundamental unit on which all the many complex dimensions of tourism are based" [2]. For the first time, in 1979, tourism as a phenomenon has been officially defined through the notion of "tourist destination" by the British Tourism Society [3]. If during the 1990s few authors were writing about concepts like place/tourist destination branding, place/tourist destination marketing, or place/tourist destination management, after 2000, all these concepts started to bloom and nowadays there is truly fertile scientific literature in the field of tourist destination management and marketing [1,4,5]. This process of conceptual development took place due to a real need: For tourist destinations, being unique places with particular characteristics and specific needs, the traditional marketing and management approach was no longer enough to cover and treat all aspects related to such complex structures. Therefore, the process of strategic planning of tourist destinations always involves several dimensions and stakeholders. Managing tourist destinations means creating and developing places which satisfy the real needs of consumers/tourists, where the local population and businesses prosper, and where there is a proper balance between the impact of tourism (costs) and all the benefits it brings. In this context, developing tourism in a sustainable way appears to be the most appropriate solution for the management of tourist destinations [6].

If "tourist destination" is considered a complex concept, the "competitiveness of tourist destinations" is an even more complex one. As Pike suggested, the battle for gaining competitive advantage is no longer a battle of products and services, but a battle of the tourists' perceptions; therefore, it is a battle that takes place inside the tourists' mind [7]. From the beginning of the 1980s, tourism competitiveness started to be defined through two central concepts: profitability and sustainability. Therefore, one of the simplest definitions of tourist destination competitiveness has been formulated by Buhalis [1] as being the "long term success" of a tourism area. A successful destination is the tourism area which continuously attracts the desired tourists through quality and unique experiences and which continuously develops, ensuring benefits for all the stakeholders, for the entire local community, and for the place itself (resource preservation). The process of continuous development should follow the sustainable way in order to provide long-term success. This approach has been recently highlighted by the World Economic Forum, which, since 2007, has been releasing the Tourism and Travel Competitiveness Index, one of the most detailed and comprehensive studies regarding the tourism performances of world countries as macro-tourist destinations [8]. In the 2015 report, the experts from the World Economic Forum stated that the aim of the Competitiveness Index is "to provide a comprehensive strategic tool for measuring the set of factors and policies that enable the sustainable development of the Travel \& Tourism sector, 
which in turn, contributes to the development and competitiveness of a country" [8]. In order to emphasize the relationship between sustainability and competitiveness, it was recently declared that a destination which does not develop in a sustainable way cannot be a competitive destination [2].

However, competitive advantage can only be obtained through a strategic planning approach [3]. Usually, Destination Management Organizations (DMOs) are responsible for strategically planning the development of tourist areas, but if no DMO exists, local authorities become the decision-makers. Within the process of strategically planning the way a tourist destination gains competitive advantage, evaluation plays a crucial role; the entire process is based on the correct, sincere, and comprehensive evaluation of the destination. After that, strategies can be formulated and action frameworks can be built and implemented periodically.

Also, in the same context, the correct evaluation of the external environment (social, political, economic and technological) is of vital importance and the focus always should be on consumers/tourists. For example, we are currently witnessing a major generational shift, with Generation $\mathrm{Y}$ entering on the scene [9-11]. The new generation of tourists and tourism employees is very different from the previous ones and the main generational gap is related to technology; starting with Generation Y, we are talking about "digital natives" [11] and "tech-savvy" people. Technology is vital for new generations. In such a generational context, decision-makers in tourism destinations have to make constant and good use of new technologies in order to keep the destinations attractive and to gain a competitive advantage [9]. Destinations also live in this new social context, with new generations of consumers who are "digital natives" and "tech-savvy". Destinations have to be attractive for these new generations of consumers, they need to convince these new consumers to come and live the tourist experience they offer; therefore, tourist destinations have to "speak" the same language as their potential consumers, being forced to adapt to the profile of this new consumer. Information and communications technology ICT and innovation are a must in current society and, for these reasons, in order to be competitive, tourist destinations have to adhere to the set of values that characterize the new generations of consumers.

In the context presented above, the current paper discusses the efforts made by the decision-makers of Europe, as a macro-tourist destination, in order to keep European destinations competitive in this new social, political, economic and technological environment. The most recent Tourism Policy adopted by the European Commission in 2010 includes several actions which aim to support European tourist destinations in gaining competitive advantage through sustainable development and best use of ICT. Several ideas included within the Tourism Policy were connected and integrated into two authentic and concrete proposals formulated in the present paper, demonstrating how this new Tourism Action Framework adopted by the European Commission provides real support for the enhancement of the competitiveness of European destinations, through making best use of innovative ICT tools.

Taking into consideration the above-mentioned definitions of the "tourist destination", Europe can be considered a specific tourist destination, along with all the places/regions included in it. Europe, as a macro-tourist destination, is managed by the European Commission through tourism policies and specific programs and actions. The European Commission is the main decision-maker for Europe. Regarding the management of the composing European destinations, there is a joint management effort because, in order to properly implement the measures adopted by the European Commission, the national and/or local stakeholders need to be actively involved. 
Developing European tourism in a sustainable way has always been a major concern for the European Commission and, within this context, the sustainable development of tourist destinations has become a focal matter. The reason why efforts have been made at the European level in order to help tourist destinations develop in a sustainable way is related to a key finding of the Commission's experts: the fact that unsustainable tourism patterns can be changed only by following two directions, the consumer behavior direction, and the production of tourism direction, which includes both tourism enterprises and destinations [6]. Because many efforts have been made at the European Union (EU) level for the sustainable development of tourism enterprises, and their impact was not the expected one, the European Commission understood that focusing on tourist destinations might be a more constructive approach. In recent years, the sustainable development of tourist destinations has become a central interest at the EU level.

In 2003, the Commission also stated its intention to "fully exploit the potential for better use of information and communication technologies (ICT)" in order to support European tourism development in a sustainable way [6] (p. 17). ICT are important tools for the promotion and distribution of tourist destinations and the experts of the European Commission proved to totally commit to this statement within the most recently adopted tourism policies. The Internet empowered both tourists and destinations. Tourists gained a significant "power of search and choice" and tourist destinations gained access to the global market and the power to "enhance the quality of the tourist experience" [2] (p. 6). However, these technologies can also become supporting tools for the development of European tourist destinations, helping them to gain a competitive advantage. At the European level, the concept of competitiveness, when it comes to tourist destinations, is based on the sustainable development of the tourism industry and the high quality of the tourism experience. The European competitive destination can therefore be defined mainly as the destination which develops in a sustainable way and offers

high-quality experiences to tourists. These two important sources for the competitive advantage of European destinations need to be addressed from the ICT perspective, because "taking advantage of new technologies and the Internet can also enable destinations to enhance their competitiveness" [1] (p. 22). This perspective is embraced by the experts of the European Commission within the newest Action Framework for European tourism adopted in 2010.

\section{A New Action Framework for European Tourism}

In 2009, eight key megatrends were identified as strongly affecting the European tourism industry, including access to information, sustainability, and experience economy [12]. In order to remain competitive, Europe needs to find ways to face the challenges determined by these megatrends and:

- make the tourism industry part of the knowledge economy;

- develop EU tourism in a sustainable manner;

- better position the EU as the number one provider of authentic and quality tourist experiences.

The most recent European Tourism Policy, communicated by the European Commission in 2010, takes into consideration all these above-mentioned factors. The architecture of the policy is based on four priorities, all related to better promoting European tourism [6]. For each priority, several specific 
actions are proposed. Only actions of direct interest for the topic of the present paper will be shortly mentioned below.

The first priority within the policy is to stimulate competitiveness in the European tourism sector. Due to the fact that a close relationship has been identified between innovation and competitiveness, several concrete actions have been proposed in order to reach the goal of developing innovation in the European tourism industry. Action no. 3 is related to the creation and launching of an "ICT and tourism platform for stakeholders to facilitate the adaptation of the tourism sector and its businesses to market developments in new information technologies and improve their competitiveness by making the maximum use of possible synergies between the two sectors" [6] (p. 8). In order to encourage the extension of the tourism season, action no. 7 proposes to "develop a voluntary online information exchange mechanism to improve the coordination of school holidays in the Member States, without prejudice to their cultural traditions" [6] (p. 9). With the main aim of consolidating the socioeconomic knowledge base for tourism, the Commission intends to create a "virtual tourism observatory to support and coordinate research activities by the various national research institutes (research institutes, universities, public and private monitoring units, regional and national authorities and national tourism offices)" [6] (p. 10).

The second priority within the policy is to promote the development of sustainable, responsible and high-quality tourism. Action no. 11 presents the intention of the European Commission to develop a genuine set of indicators for evaluating the sustainability performances of European tourist destinations, followed by the creation of a label for promoting European sustainable destinations. Action no. 13 declares the intention of the Commission to develop a European "High Quality" label [6] (p. 11). Even if the two above-mentioned actions have no ICT elements, they have been noted within this paper because several proposals will be presented in the following section that introduce an ICT component.

The third priority within the policy is to consolidate the image and profile of Europe as a collection of sustainable and high-quality destinations. Action no. 19 states that efforts need to be made to promote the European tourism web-platform [13] "in order to increase the attractiveness of Europe as a collection of sustainable and high-quality tourist destinations, particularly among emerging countries" [6] (p. 10).

The fourth priority within the policy is to maximize the potential of EU financial policies and instruments for developing tourism but, unfortunately, it only expresses the intention of the European Commission to support innovative initiatives in the future, with no specific action or instrument.

Taking into consideration the above-mentioned priorities and selected actions which have been included within the most recent European Tourism Policy, adopted in 2010 by the European Commission, the present paper focuses on demonstrating how these ideas, formulated by European experts, can be implemented at the destination level in order to enhance competitiveness.

\section{ICT Tools for Competitive European Tourist Destinations}

Tourist destination competitiveness was defined in the tourism literature as "its ability to increase tourism expenditure, to increasingly attract visitors while providing them with satisfying, memorable experiences, and to do so in a profitable way, while enhancing the well-being of destination residents and preserving the natural capital of the destination for future generations" [2] (p. 2). 
As Ritchie and Crouch stated, tourist destination competitiveness is a multidimensional concept, including economic competitiveness, political competitiveness, sociocultural competitiveness, environmental competitiveness, and technological competitiveness [2]. As a consequence, in order to gain a competitive advantage, tourist destinations need to harmoniously combine all the above-mentioned dimensions of competitiveness.

The two great sources for competitive advantage identified by the European Commission within its most recent Tourism Policy are: sustainability and high quality. However, due to the large access to information and to the new generational context with more and more consumers who are "digital natives" and "tech-savvy", European decision-makers also need to find ways to "make the tourism industry part of the knowledge economy", as stated in the previous section. In such a context, several initiatives and projects which genuinely combine ICT and sustainability or high-quality promotion have been proposed and even totally or partially implemented at the EU level. Also, further possibilities for innovation can be identified and formulated in these areas.

One of the first projects that combined ICT and the promotion of European tourist destinations was the creation of the web platform VisitEurope [13] in 2006, where all European tourist destinations are being promoted. In 2009, the web platform was improved and, in 2011, its Chinese version was launched. Also, the Virtual Tourism Observatory (VTO) website [14] and the Calypso web platform [15] have become functional. Several projects were co-financed by the European Commission, such as KNOWNET or FAST LANE [16]. All the above-mentioned projects mainly aim to promote and inform.

The TOURISMlink Project is a very important initiative funded by the European Commission. with its main target "to increase the competitiveness of small and medium enterprises (SMEs) across Europe in today's digital marketplace" [17]. The project is not completely finished, but the TOURISMlink platform was developed to offer three main elements: "a central reservation system (CRS) that centralizes all products and destinations into one database; a property management system (PMS); and channel management, allowing immediate and automatic integration and adaptation of all data" [17]. The TOURISMlink Project represents the implementation of action no. 3 from the newest European Tourism Policy, as it was cited above. The TOURISMlink Project is the perfect demonstration of how business intelligence and innovation can be used to offer real support to tourist destinations and businesses in order to enhance their competitive advantage. The entire project is based on the European principles of sustainable development, transforming the participating destinations and businesses into real partners.

Acknowledging the fact that tourism management is considered the key to gain and maintain competitive advantage [2], we affirm that more tools to support the management of tourist destinations should be encouraged, funded, and implemented at the EU level in order to help European tourist destinations gain a competitive advantage, following the successful example of the TOURISMlink web platform. Two such proposals will be introduced in the following paragraphs. Both proposals combine the concepts of competitiveness and ICT, being concrete examples of how innovative business intelligence tools can be developed in order to contribute to the performance management at the destination level, enhancing the competitiveness of European destinations. Also, both proposals are placed within the new generational context. The new generation of "digital natives" is entering the tourism market as well as the workforce. Tourists, employees, and managers need technology because it is a vital part of their lives. They make decisions based on and using new technologies and they completely understand the 
benefits of using innovative ICT tools. Therefore, both proposals respect this trend, which was also reinforced within the new Tourism Action Framework formulated in 2010 by the experts of the European Commission. Due to this new social context, innovation and new technologies became vital elements in order to gain a competitive advantage in tourism, as mentioned within the most recent European Tourism Policy [6].

\subsection{Development of a Decision Support System for Managing European Tourist Destinations in a Sustainable Way}

One of the priority areas identified by the experts of the European Commission in 2000 was to create tools for the benchmarking of European destinations in order to help them improve the quality of tourism. Also, for the first time, the need to create business intelligence tools like Destination Management Systems in order to integrate information and communication technologies in the tourism sector at the European destination level was mentioned [18] (p. 27). In 2001, the Commission stated the necessity to conceive and disseminate authentic tools and assessment methods for monitoring and benchmarking European tourist destinations [18] (p. 18). In 2013, the European Commission successfully implemented action no. 11 from the newest European Tourism Policy and delivered a genuine set of 67 indicators for the evaluation and benchmarking of sustainable European tourist destinations called the ETIS system (European Tourism Indicators System for Sustainable Destinations). As we have already proposed in a recent article [19], an innovative decision support system for tourist destinations management can be developed based on the ETIS indicators.

In 2014, based on the proposal presented above, the DIMAST Pilot Project (Destination Intelligent Management for Sustainable Tourism) [20] received financial support from the EU Structural Funds Program by the Executive Unit for Financing Higher Education, Research Development and Innovation in Romania. It is a collaborative applied research project, based on a consortium of seven partners (a university, a national research institute, a destination management organization, a non-governmental organization (NGO) for sustainable development, two tourism and hospitality enterprises, and a software firm), which is currently entering in its second phase, as shown in Figure 1. The DIMAST Project focuses on the design and development of an original and innovative technical process for implementing the European Tourism Indicators System for Sustainable Destinations (ETIS), through a group decision support system (GDSS). The project focuses on the county of Brasov, which is a top all-year-round destination in Romania. Due to the pronounced heterogeneous character of this tourist destination, the DIMAST project aims to create a flexible business intelligence solution that is highly adaptable to other European destinations willing to implement the ETIS System using ICT and develop in a sustainable way. One of its final goals is to create an innovative ICT tool which directly and actively supports the participatory management of sustainable tourism development at the destination level and is capable of offering real support to the achievement of long-term competitiveness for European destinations. 


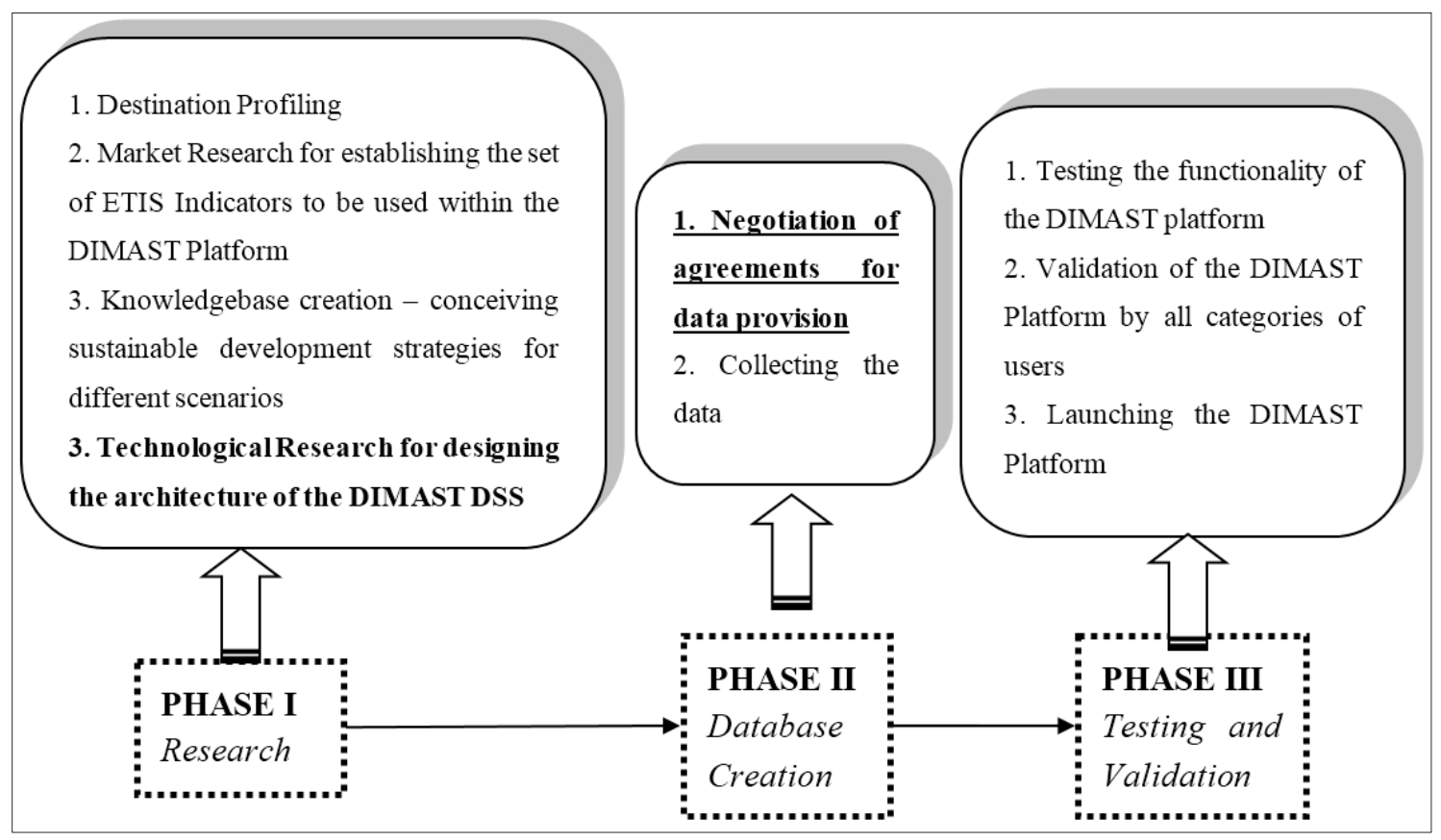

Figure 1. The three main phases of the DIMAST Project.

A tourist destination cannot gain competitive advantage by accident [3]; it is the result of a constant planning process. It was demonstrated that enterprises that use planning procedures have significantly higher performances compared to businesses that do not [3]. In such a context, more and more business intelligence solutions have been developed in order to support the planning process of enterprises, most of them being decision support systems (DSS). Due to the infinite possibilities of conceiving such systems, no broad and exact definition for a DSS can be formulated [21]. Nevertheless, taking into consideration the practical aims of a DSS, it can be concisely defined as an interactive software-type product that aims to assist the decision-makers within an organization to solve problems and/or take the best decisions in a given context through data interpretation and correlations [22]. An innovative computerized decision-making support system should support the decision-making process and not generate automated decisions [23]. The above-presented discussion perfectly fits the tourist destination management sector, too, but, as Buhalis and Costa [24] recently noticed, there are only a few projects approaching this issue and they are considered highly innovative; most decision-makers at the destination level do not know about the possibility of using such business intelligence tools in order to increase the competitiveness level of destinations. It has been recently stated that DSS systems can play a fundamental part within the decision-making process of tourist destinations, significantly contributing to formulating policies and strategies, to destination development, and to the implication of all the stakeholders [24]. As we have mentioned above, the European Commission has been supporting this perspective since 2000 [18]. Analyzing the recent tourism literature, a small number of studies which treat the idea of designing decision support systems for tourist destinations management was identified; some of these are just theoretical articles proposing the development of such systems $[22,25]$ and only a few take into account the need for sustainability within European tourism destinations [26-30]. Nevertheless, most of these projects that have been implemented at the European level are not functional any longer. A successful and still-functional project is the TourMIS Platform [31,32], co-financed by the Austrian government, offering a decisional support system for tourist destination marketing. This 
system has been put together by the Modul University specialists in Vienna and was conceived to regroup different tourism stakeholders within a web platform upheld by a database, being one of the strengths of TourMIS through its user-friendly access. The platform not only addresses to tourist destinations' decision-makers, it also creates reports and useful information for a number of other organizations as well. The system also offers benchmarking features for tourist destinations willing to compare their performances. However, TourMIS does not clearly aim toward a sustainable development of tourism and this is the most significant difference in comparison with the DIMAST Project.

The DIMAST Project [20] is based on the ETIS tool created by the experts of the European Commission as a support tool for European tourist destinations willing to develop in a sustainable way and, accordingly, achieve a long-term competitive advantage. It is the first implementation project that includes the ICT component, aimed at transforming the ETIS tool into a more practical, useful and easy-to-implement instrument for European destinations interested in following the sustainable way, according to the European Union's principles. The innovative DIMAST DSS will be built on: (1) a database (primary and secondary data), mainly conceived of the selected ETIS indicators, (2) a specialized knowledgebase in the field of sustainable tourism strategies, (3) a model and algorithm base used for data processing, and (4) a geographic information sub-system (GIS) for the creation of thematic maps based on key indicators included in the project. The DIMAST system functionality will be tested through an integrated web platform. Being designed as a collaborative DSS (GDSS), the DIMAST Project includes several categories of users: the main user is the Destination Management Organization (DMO) and there are also three additional categories of (1) tourism and hospitality enterprises; (2) research organizations; and (3) other entities that might be interested in sustainable development. The basic architecture of the DIMAST GDSS is presented in Figure 2 below.

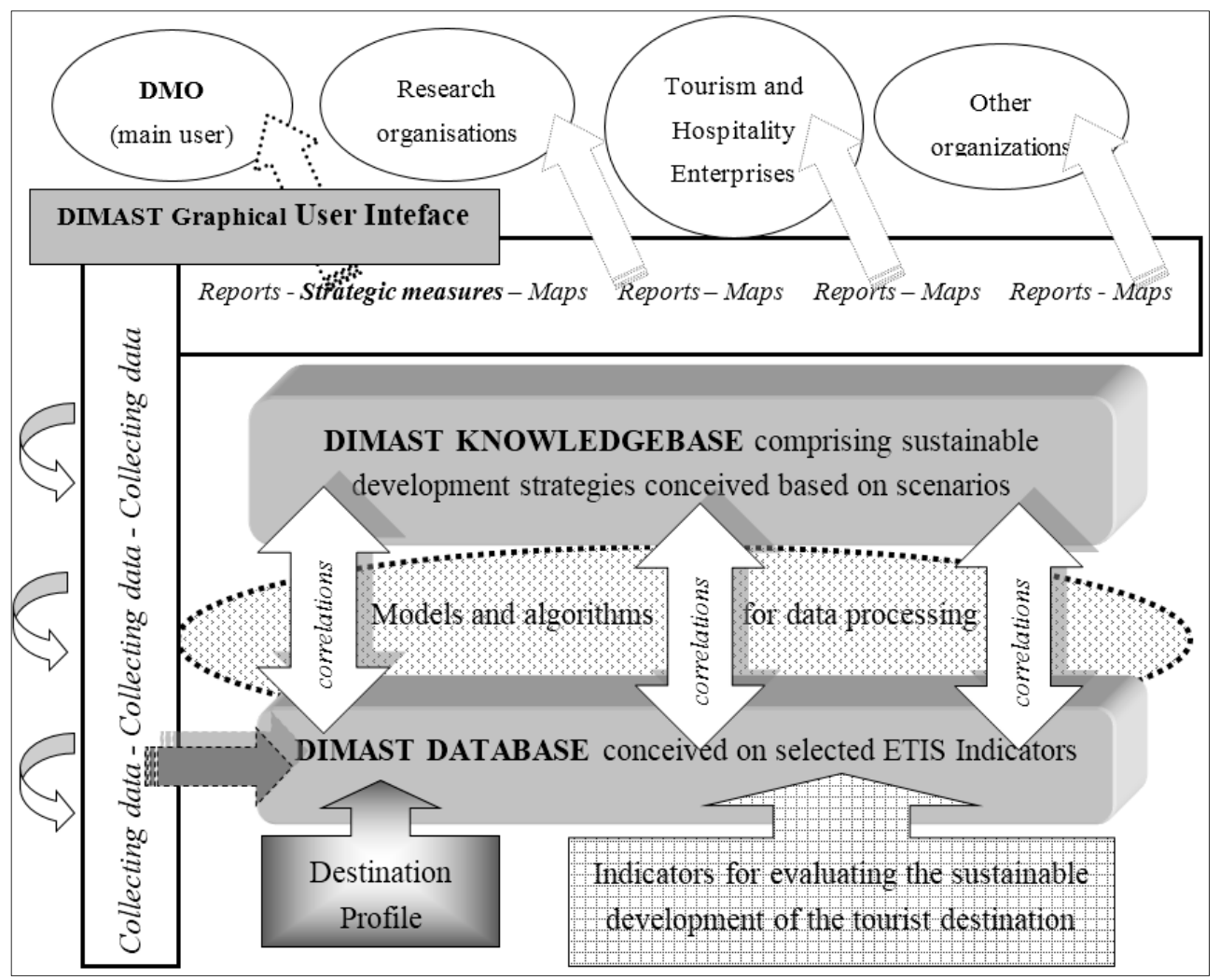

Figure 2. DIMAST DSS basic architecture. 
The main objective of the DIMAST Project is to create an innovative ICT tool which can bring a real and useful contribution to the sustainable development of European destinations. If correctly implemented by several European destinations, it can develop into a European benchmarking tool for sustainable destinations $[33,34]$. By all means, the ultimate aim of the DIMAST DSS is to help European tourist destinations gain a long-term competitive advantage.

The proposal presented above, using the case study of the DIMAST Project, provides a concrete example of how the new Tourism Action Framework, proposed by the European Commission in 2010, can contribute to raising the competitiveness of European destinations through ICT innovative tools. The ETIS System of Indicators has been created based on this new Tourism Action Framework as an important management instrument for the decision-makers in European destinations who are willing to develop their destinations in a sustainable and, thus, competitive way. Including the technological dimension and creating a business intelligence instrument based on ETIS can provide significantly higher visibility and attractiveness for the ETIS tool and, therefore, exponential long-term benefits for European destinations. Using specialized software with a user-friendly interface which also offers strategic decision support is definitely much more attractive for decision-makers at the destination level who are willing to implement ETIS or who only want to manage their destinations toward gaining a long-term competitive advantage.

This proposal is directly addressed to decision-makers at destinations. The importance of conceiving such innovative business intelligence tools to support the management of tourist destinations has been acknowledged by the European Commission since 2000 in the context of a changing social, political, economic, and technical environment. These solutions proved to be beneficial for businesses and, at the same time, the new generations of employees and managers who have vital needs regarding the use of new technologies [11]. In such a context, proposing, designing and implementing innovative ICT solutions for the people who work and will work in destination management teams, such as the DIMAST Project, is the natural way of supporting the long-term competitiveness of European destinations. The proposal presented above also has an important asset - the European added value — due to the fact that it is based on ETIS, which is a European product issued by the European Commission within the process of implementing the new Tourism Action Framework.

\subsection{Development of a Decision Support System Based on an Umbrella European Certification/Labeling} System for Tourism Quality

In 2007, the European Parliament addressed the invitation to Member States and European tourism and hospitality enterprises to set up quality management schemes [35]. Nowadays, there are many tourism quality-labeling and standardization schemes which coexist at the European level, both private and public, local and national; however, as noticed by European experts [36,37], they lack consistency "when compared in respect of their sectorial scope, geographical coverage, governance, assessment".

The existing market is highly fragmented and the European added value cannot be found in any of these existing schemes. In such a context, the new Tourism Action Framework adopted by the European Commission in 2010 introduced the proposal to develop a European Tourism Quality Label, as mentioned above in this discussion paper. As noticed in this policy document, progress has been made in the direction of developing a European "Qualité Tourisme" brand, in order to "increase consumer security 
and confidence in tourism products and reward rigorous efforts by tourism professionals whose aim is quality of tourism service for customer satisfaction" [6] (p. 10). After the launching of the new Tourism Action Framework by the European Commission, an important study has been conducted on the estimated impacts, possible options, and legal instruments of the umbrella European tourism label for quality schemes [37]. In 2014, the European Commission conceived a formal legal proposal for a Council Recommendation on European Tourism Quality Principles [36]. The document explains in detail the necessity to introduce a set of common Tourism Quality Principles at the European level and proposes a minimal set of such principles "applicable to tourism services offered in the Union directly to consumers and (which) are recommended to be followed by public and private organizations providing services in the field of tourism" [36]. The formulation of a set of European Tourism Quality Principles was a necessary step on the way to adopting an umbrella European Quality Tourism Label in the future. The creation of such an instrument would help "quality-sensitive consumers to make better informed choices" [36], would support and reward the efforts of tourism and hospitality enterprises regarding the provision of higher and higher qualities of their products and services, and would also contribute to image and brand improvement of European destinations and, therefore, support their long-term competitiveness.

Within this context, we suggest that an innovative decision support system (DSS) for tourists willing to visit Europe can be developed based on a genuine umbrella "Qualité Tourisme" certification/labeling system adopted at the European level.

As we have already proposed in a recent article, several ICT innovative tools can be developed at the destination level in order to provide support for tourists who want to make responsible choices for their vacations [38]. The demand of planning tools for tourists was determined by the need of gaining more time for the vacation. In order to plan a vacation, tourists usually have to spend their time collecting information about the desired destination and the points of attraction they are going to visit. As a result, establishing the desired route at a destination is a time-consuming task for tourists [39] and ideas for addressing this problem arose. It has been stated that "web based decision support applications are excellent aids for tourists who want real support for tourist planning problems" [40]. This so-called "touristic trip planning problem" [41] has been addressed in the last decade by several authors in scientific research papers [40-50], proposing the creation of decision support systems for tourists, both web-based and mobile, generally called "trip planners". These instruments mainly serve to tailor a trip according to the specific needs and interests of a tourist/group of tourists and usually produce trip plans or trip maps. It has been said that these recent developments revolutionized tourism [40]. However, taking into consideration the recent research findings regarding the way of thinking and the real needs of current consumers [9-11], such trip planners, mainly conceived for mobile devices, are tailored for the profile of the consumer who belongs to the new generation of "digital natives" and "tech-savvy" people.

In the context presented above, the proposal formulated within this section is highly innovative. Exactly like the first proposal, presented in the previous section of this discussion paper, a DSS for tourists based on an umbrella European certification/labeling system for tourism quality represents a concrete example of how the new Tourism Action Framework adopted by the European Commission can be implemented. Even if such a DSS is mainly conceived for tourists, offering real support for the "quality-sensitive" tourists, it also contributes to raising the competitiveness of tourist destinations 
willing to implement this kind of ICT instrument, as stated before. However, important steps need to be taken at the European level before such an approach can be transformed into reality. First of all, significant efforts have to be made in order to create the umbrella European certification/labeling system, "Qualité Tourisme". Developing a European trip planner based on "Qualité Tourisme" would definitely provide higher visibility and attractiveness for such a European umbrella certification/labeling system, making it easier to implement.

Both proposals presented above need to be developed and properly implemented in European destinations by specific stakeholders in order to bring a real contribution to the long-term competitiveness of the local area where their importance is acknowledged. As a result, the problem of understanding and assuming roles and responsibilities regarding the implementation of the Tourism Action Framework at the destination level needs further clarification.

\subsection{Roles and Responsibilities Regarding the Competitiveness of European Tourist Destinations}

As mentioned above, the concept of "tourist destination" is a complex one; the tourist destination is both tangible and intangible, it is a place situated in a specific area, with specific physical and geographical coordinates, but also an intangible socio-cultural entity, mainly represented by the people, traditions, lifestyle, culture, and social interactions within it [51]. At the same time, the tourist destination is an image and an experience which exists in the consumers' minds and souls. Everything a tourist destination represents can be integrated within a unique brand. New important concepts appeared in the tourism literature in this context, such as a destination's personality, spirit or profile [34,52,53]. Taking into consideration all these aspects, tourist destinations are specific entities with specific needs which are not very easy to manage. In order to properly manage a tourist destination, the responsible stakeholders have to understand the specific needs of the destination, correctly prioritize them, and always start from the premises that tourist destinations are living entities with a particular sinusoidal life-cycle. All these concepts enable us to make analogies of tourist destinations and human beings. Therefore, based on Maslow's Hierarchy of Needs [54], the present discussion paper proposes the creation of a pyramidal model called Destination's Hierarchy of Needs, graphically depicted in Figure 3.

Within the Destination's Hierarchy of Needs, each level of specific needs represents, at the same time, a level of responsibilities for the destination's stakeholders. In order to properly fulfill the destination's specific needs, different stakeholders share specific roles. Therefore, a tourist destination's competitiveness highly depends on the degree stakeholders are aware of and assume their roles and responsibilities [55]. In other words, there is a relationship of direct determination between the social capital of a tourist destination and its competitiveness.

There are three main categories of stakeholders who share responsibilities regarding the competitiveness of a destination: public stakeholders, private stakeholders, and the local community [1]. In the context of the discussion of this paper, it is of vital importance to identify those stakeholders who become decision-makers within the process of implementing the European Tourism Action Framework at the destination level. From a theoretical perspective, a Destination Management Organization (DMO) should have such responsibilities and roles as a unique entity which makes and assumes decisions for the entire destination $[1,56]$. However, at the European level, there is a great diversity and broad typology of tourist destinations and the percentage of European destinations which have a legal and functional 
DMO is not significant yet, but it is continuously growing. Therefore, local authorities play a crucial role in the process of strategic implementation of the European Action Framework for tourism.

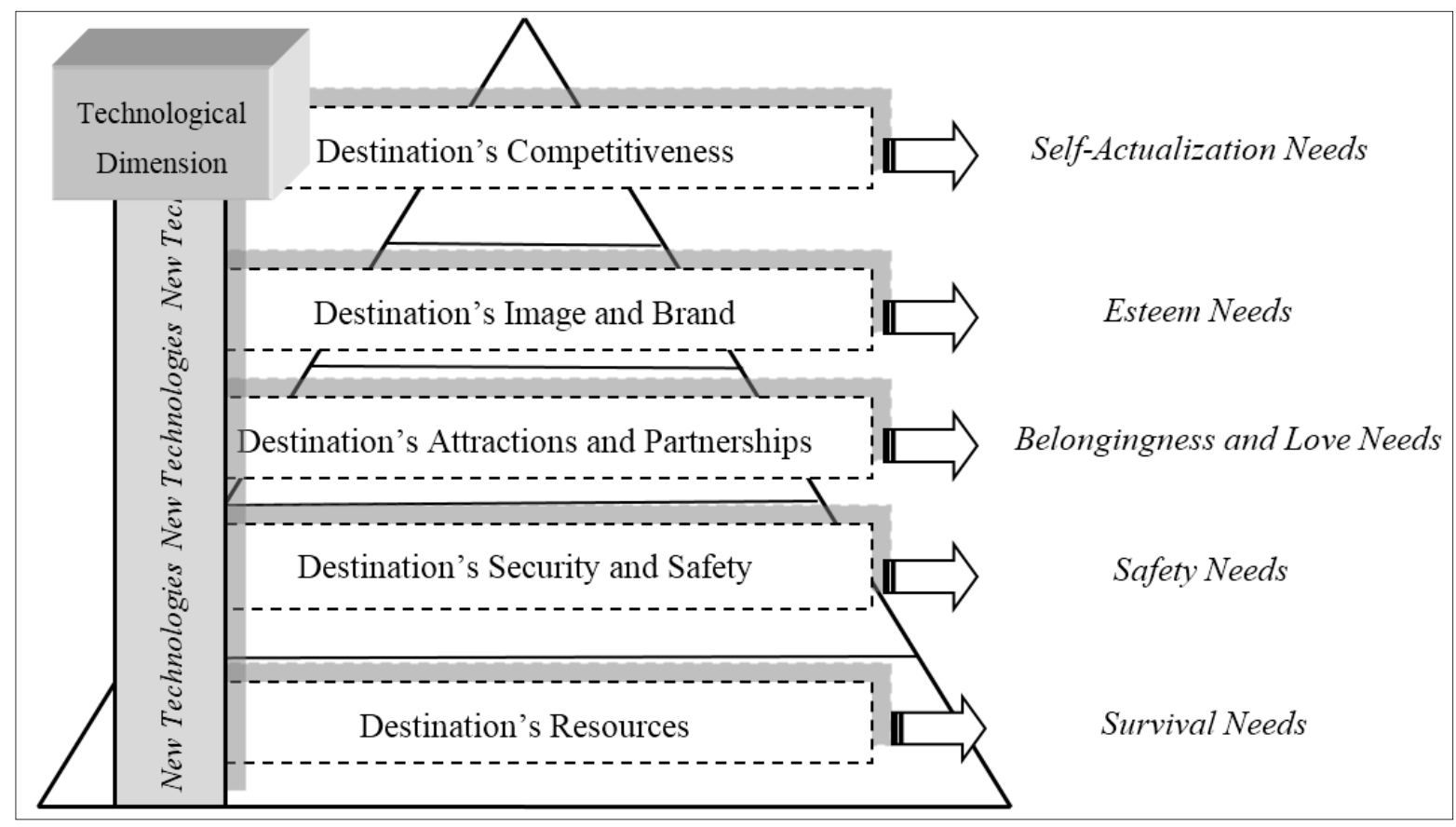

Figure 3. Destination's Hierarchy of Needs.

As presented above, the European perspective on a destination's competitiveness strongly relies on sustainable development and high quality. In the new generational context, we support the idea that local decision-makers at European destinations should focus on identifying ways to make better use of ICT in order to develop the technological strengths of destinations. The present discussion paper introduced two ideas of how innovative ICT tools can be developed in order to better implement the new Tourism Action Framework adopted by the European Commission at the destination level, aiming to increase the competitiveness level. However, there are infinite possibilities to strengthen the technological dimension of the competitiveness for tourist destinations. It should be a focal preoccupation for decision-makers at the destination level because the new generation of tourists are tech-savvy, and they are the "digital natives" [11]; technology is a natural (and vital) part of their lives and their specific profile requires specific strategic measures at the destination level as well [9-11]. New technologies can actually be used for satisfying all the levels of a destination's needs, as presented in Figure 3 above. As stated by Law, Leung and Buhalis [47], ICT can bring a real contribution to the dynamic management of information by destination decision-makers, offering them true support in the strategic planning process and, therefore, positively influencing the competitiveness of tourist destinations.

The discussion within this paper focused on the relationship between competitiveness, sustainable development, and innovative ICT solutions at the tourism destination level. The new Tourism Action Framework proposed by the European Commission in 2010 is based on this trinomial. According to European experts from the European Commission, there can be no competitiveness without sustainable development. Short-term competitive advantage no longer exists from a European perspective because this concept proved to have no solid foundation. Only long-term competitiveness is acceptable at the European level, which is based on constant efforts to develop tourism areas and businesses respecting 
the European sustainable development principles. The new generational context, with the $\mathrm{Y}$ generation (and after it, the Z generation) of "digital natives" and "tech-savvy" people entering the workforce and the tourism market, forces tourist destinations and businesses to re-profile according to the new sets of values that characterize these new cohorts. Nowadays, both tourists and tourism employees need ICT and new technologies in order to make decisions; it is a vital part of their lives. In such a context, innovation has become a "must" in all industries, tourism included. Therefore, tourist destinations definitely need to develop innovative solutions based on new technologies in order to enhance long-term competitiveness, as the experts of the European Commission have constantly acknowledged since 2000. With respect to the new generational profile, long-term competitiveness can only be achieved through innovation and proper use of new technologies. Taking into consideration this new social context, it is the ultimate sustainable approach. Forasmuch as the present discussion demonstrated, the relationship between destination competitiveness, sustainable development, innovation and ICT may be considered a symbiotic one and, due to this specific nature, decision-makers of European destinations need to conceive strategies based on this trinomial, sustainable development-innovative ICT solutions competitiveness.

\section{Conclusions}

Managing and marketing tourist destinations are very difficult and challenging activities, due to the complexity of the concept of the "tourism destination" itself [1]. European destinations need to be managed in a sustainable way because, due to the high demand for tourism in Europe, travel intensity will increase in the future and there is a risk of partially or completely damaging its resources. All efforts made at the European level regarding the sustainable development of tourism need to be assisted by appropriate information tools and networks.

Important steps have already been made at the European level in the direction of combining sustainability, promotion, and high-quality aspects with ICT with the main aim of offering support to tourism enterprises and destinations in order to gain a competitive advantage. Important related actions are included within the new framework for action established by the European Commission in the most recent Tourism Policy, adopted in 2010. Some of them have already been successfully implemented.

Concepts like "technological strengths of tourist destinations" have only recently started to be used [2] (p. 5). Taking into consideration the technological dimension of the competitiveness, this should be a focal point for European tourist destinations in the near future, finding the best ways to develop technological strengths through innovative approaches based on the main existing assets that are the sustainable development and the high quality of European tourism. Starting with the simple Internet promotion and following with establishing collaborative web platforms and all types of business intelligence tools, the decision-makers at European destinations should find innovative ways to implement the new Tourism Action Framework adopted by the European Commission through ICT applications. Two such examples were formulated within the present discussion paper. The first one introduced the DIMAST Project, which aims to develop a flexible and adaptable DSS for tourist destinations willing to develop in a sustainable way, based on the ETIS Indicators System launched by the European Commission in 2013. The project is in progress, as shown in Figure 1. The second proposal formulated within the present discussion paper presents the idea of developing a trip planner based on the umbrella European 
certification/labeling system, "Qualité Tourisme", which will be created in the near future, as stated within the new Tourism Action Framework.

Within the new context created at the European level by the Lisbon Treaty, which introduced a new competence and, therefore, new powers for the European Union to complement the action of Member States in the tourism sector [57], the two proposals formulated within the present discussion paper represent concrete examples of how the new Tourism Action Framework adopted by the European Commission in 2010 can directly contribute to the enhancement and promotion of the long-term competitiveness of European destinations, through making the best use of innovative ICT tools. As it has been emphasized all through the present discussion paper, taking into consideration the present social, economic, and technological context, creating innovative tools based on new technologies is the only path to follow in order to enhance competitiveness. The new generations of "digital natives" and "tech-savvy" people live their lives, make their decisions, and depend on new technologies [11]. In respect of this symbiotic relationship, which characterizes the present social context, the natural way is to develop business intelligence tools tailored to the profile of these new consumers and new employees/managers. The European experts from the European Commission correctly identified this new profile in 2000 [18], and have been proving their commitment to respect it ever since. Therefore, in the most recent Tourism Policy, "innovation" and ICT/new technologies are keywords for competitiveness enhancement. European destinations need to adapt their profile to one which characterizes the new generation in order to gain a long-term competitive advantage.

Ali and Frew [58], in their recent paper, advanced the idea of the great value that social media has for sustainable tourism. In the context of this discussion paper, we support the idea that the European Commission and European destinations should also concentrate on using social media and transforming it into powerful strengths. There is also room for innovation within this field, due to the fact that a new concept appeared: Web 3.0 or the Semantic Web. This is a new direction for future research at the European level.

\section{Acknowledgments}

This paper is supported by the Sectorial Operational Programme Human Resources Development (SOP HRD), financed from the European Social Fund and by the Romanian Government under the Project number PODRU/159/1.5/S/134378.

\section{Author Contributions}

Ray Iunius, Laura Cismaru and Diana Foris equally contributed to this discussion paper. Respectively, Laura Cismaru and Diana Foris analyzed the research concepts within the most recent Tourism Policies adopted by the European Commission, Ray Iunius and Laura Cismaru formulated and depicted the innovative proposals within the discussion paper, and Diana Foris collected the research resources and systematized the content.

\section{Conflicts of Interest}

The authors declare no conflict of interest. 


\section{References}

1. Buhalis, D. Marketing the Competitive Destination of the Future. Available online: http://core.ac.uk/ download/pdf/101658.pdf (accessed on 27 Fabruary 2015).

2. Ritchie, J.R.B.; Crouch, G.I. The Competitive Destination: A Sustainable Tourism Perspective; CABI Publication: Cambridge, UK, 2003.

3. Vanhove, N. The Economics of Tourist Destinations; Butterworth-Heinemann: Oxford, UK, 2005.

4. Kotler, P.; Bowen, J.; Makens, J. Marketing for Hospitality and Tourism; Prentice Hall: Upper Saddle River, NJ, USA, 1999.

5. Nicolaescu, L. Zooming the Image of Romania. Country Branding and Rebranding; The Academy of Economic Sciences: Bucharest, Romania, 2008.

6. European Commission. Europe, the World's No 1 Tourist Destination-A New Political Framework for Tourism in Europe. Available online: ec.europa.eu/enterprise/sectors/tourism/ documents/communications/commission-communication-2010/index_en.htm (accessed on 18 September 2015).

7. Pike, S.D. ToMA as a measure of competitive advantage for short break holiday destinations. J. Tour. Stud. 2002, 13, 9-19.

8. Crotti, R.; Misrahi, T. (Eds.) The Travel \& Tourism Competitiveness Report 2015. Growth through Shocks; World Economic Forum: Geneva, Switzerland, 2015.

9. Cismaru, L.; Iunius, R. Rural tourist destinations and the tourists of Generation Y. In Romanian Rural Tourism in the Context of Sustainable Development. Present and Future Perspective; Paduraru, T., Tacu, G., Ungureanu, D., Talaba, I., Eds.; PIM Publication: Iasi, Romania, 2015.

10. Benckendorff, P.; Moscardo, G.; Pendergast, D. Tourism and Generation Y; CAB International: Beijing, China, 2010.

11. Prenksy, M. Digital natives, digital immigrants. Horizon 2001, 9, 1-6.

12. ECORYS SCS Group. Study on the Competitiveness of the EU Tourism Industry-with Specific Focus on the Accommodation and Tour Operator \& Travel Agent Industries. Final Report to Directorate-General Enterprise \& Industry. Available online: http://ec.europa.eu/enterprise/sectors/ tourism/files/studies/competitiveness/study_on_tourism_competitiveness_2009_en.pdf (accessed on 21 February 2015).

13. Visiteurope. Available online: http://www.visiteurope.com/en/ (accessed on 12 March 2015).

14. European Commission's Virtual Tourism Observatory (VTO). Available online: https://ec.europa.eu/ growth/tools-databases/vto/home (accessed on 12 March 2015).

15. eCalypso. Available online: http://www.ecalypso.eu/steep/public/index.jsf (accessed on 11 March 2015).

16. European Commission. Implementation Rolling Plan of Tourism Action Framework. Available online: http://ec.europa.eu/enterprise/sectors/tourism/files/communications/com_implementation_ rolling_plan_en.pdf (accessed on 12 March 2015).

17. TOURISMlink. Linking Tourism Professionals with the Digital Market. Available online: http://www.tourismlink.eu/the-project/what-is-tourismlink/ (accessed on 13 March 2015). 
18. European Commission. Commission communication to the Council, the European Parliament, the Economic and Social Committee and the Committee of the Regions: Working Together for the Future of European Tourism. Available online: http://aei.pitt.edu/5237/1/5237.pdf (accessed on 18 September 2015).

19. Brătucu, G.; Cismaru, L. The sustainable development of the Euroregions, as tourist macro destinations, through an informatics decision support system based on the European Tourism Indicators System for Sustainable Destinations launched by the EU Commission in 2013. In Sustainable Economic and Social Development of Euroregions and the Cross-border Areas, Proceedings of the International Conference Sustainable Economic and Social Development of the Euroregions and the Cross-border Areas, Balti, Moldova, 27 June 2014; Tehnopress: Iasi, Romania, 2014; pp. 45-61. (In Romanian)

20. DIMAST Homepage. Available online: www.dimast.eu (accessed on 20 March 2015). (In Romanian)

21. Keen, P.G.W. Decision support systems: A research perspective. In Decision Support Systems: Issues and Challenges; Fick, G., Sprague, R.H., Eds.; Oxford Pergamon Press: Oxford, UK, 1980.

22. Baggio, R.; Caporarello, L. Decision Support Systems in a Tourism Destination: Literature Survey and Model Building. In Proceedings of the itAIS 2005-2nd Conference of the Italian chapter of AIS (Association for Information Systems), Verona, Italy, 1-2 December 2005; pp. 1-15.

23. Alter, S.L. Decision Support Systems: Current Practice and Continuing Challenges; Addison-Wesley series on decision support; Addison-Wesley: Upper Saddle River, NJ, USA, 1980.

24. Buhalis, D.; Costa, C. Tourism Management Dynamics; Routledge: London, UK, 2012.

25. Singh, S.P.; Sharma, J.; Singh, P. A Web-based Tourist Decision Support System for Agra City. Int. J. Instrum. Control Autom (IJICA) 2011, 1, 51-54.

26. Laniado, E.; Cappiello, A.; Cellina, F.; Cerioli, F.; Hernandez, K.; Laghi, A. A decision support system for sustainable tourism: The SFIDA project. In Proceedings of the ENVIROSOFT Conference, Ancona, Italy, 2-4 June 2004.

27. Laniado, E.; Botta, M.; Cappiello, A.; di Guardo, A. Environmental information systems for land planning. In Proceedings of the ENVIROINFO Conference, Geneva, Switzerland, 21-23 October 2004.

28. Balaton Project. Available online: http://www.balatonline.net_(accessed on 20 May 2014).

29. SFIDA Homepage. Available online: http://sfida-life.it (accessed on 27 February 2015).

30. Bousset, J.P.; Skuras, D.; Tesitel, J.; Marsat, J.B.; Petrou, A.; Fiallo-Pantziou, E.; Kusova, D.; Bartos, M. A Decision Support System for Integrated Tourism Development: Rethinking Tourism Policies and Management Strategies. Tour. Geogr. Int. J. Tour. Space Place Environ. 2007, 9, 387-404.

31. Wober, K.W. Information Supply in Tourism Management by Marketing Decision Support Systems. Tour. Manag. 2003, 24, 241-255.

32. Austrian National Tourist Office. Available online: http://www.tourmis.info/ (accessed on 12 May 2015).

33. Cismaru, L. European Tools for Managing and Monitoring the Sustainable Development of Tourist Destinations. Rev. Gen. Manag. 2015, 1, 101-112.

34. Cismaru, L.; Ispas, A. Improving the Profile of European Tourist Destinations through the European Tourism Indicators System. Bull. Transilv. Univ. Brasov. 2015, 8, 87-95. 
35. European Tourism Quality Principles. Available online: http://ec.europa.eu/enterprise/sectors/ tourism/quality-label/index_en.htm (accessed on 11 May 2015).

36. European Commission. Proposal for a Council Recommendation on European Tourism Quality Principles. Available online: http://eur-lex.europa.eu/legal-content/EN/TXT/?uri=celex:52014PC0085 (accessed on 18 September 2015).

37. CEPS. Estimated Impacts of Possible Options and Legal Instruments of the Umbrella European Tourism Label for Quality Schemes. Available online: http://ec.europa.eu/enterprise/newsroom/ cf/_getdocument.cfm?doc_id=7655 (accessed on 19 August 2015).

38. Iunius, R.; Cismaru, L.; Brătucu, G. The real contribution of a DSS system developed for the Sustainability oriented tourists to the sustainable development of the hospitality industry within the Euroregions. In Sustainable Economic and Social Development of Euroregions and the Cross-border Areas, Proceedings of the the International Conference Sustainable Economic and Social Development of the Euroregions and the Cross-border Areas, Balti, Moldova, 27 June 2014; Tehnopress: Iasi, Romania, 2014; pp. 101-113. (In Romanian)

39. Braunschweig, A.; Saladino, D. The Sustainability Certification for Hotels. Available online: http://www.oe-plus.ch/uploaded_files/113871571821.pdf (accessed on 17 August 2015).

40. Souffriau, W.; Vansteenwegen, P. Tourist Trip Planning Functionalities: State-of-the-Art and Future. In Proceedings of the 10th International Workshop on Web Engineering \& Tourism, Vienna, Austria, 5-9 July 2010.

41. Portolan, A.; Milicevic, M.; Zubrinic, K. Concept of Mobile Device Integration in Current Travel and Tourism Industry. In Proceedings of the 10th WSEAS International Conference on Applied Computer and Applied Computational Science, Venice, Italy, 8-10 March 2011; pp. 154-159.

42. Garcia, A.; Arbelaitz, O.; Linaza, M.; Vansteenwegen, P.; Souffriau, W. Personalized Tourist Route Generation. In Proceedings of the 10th International Workshop on Web Engineering \& Tourism, Vienna, Austria, 5-9 July 2010.

43. Godart, J.M. Combinatorial Optimisation Based Decision Support System for Trip Planning. In Information and Communicatin Technologies in Tourism; Buhalis, D., Ed.; Springer-Werlag/Wein: Berlin, Germany, 1999.

44. Goy, A.; Magro, D. STAR: A Smart Tourist Agenda Recommender. In Proceedings of the Configuration Workshop on ECAI, Valencia, Spain, 23-24 August 2004.

45. Kurata, Y. CT-Planner2: More Flexible and Interactive Assistance for Day Tour Planning. In Information and Communication Technologies in Tourism, Proceedings of the International Conference, Innsbruck, Austria, 26-28 January 2011.

46. Kurata, Y. Challenges in User-Adaptive Tour Planning Systems. In Proceedings of the AGILE 2009 Workshop on Adaptation in Spatial Communication, Hannover, Germany, 2-5 June 2009.

47. Law, R.; Leung, R.; Buhalis, D. Information Technology Applications in Hospitality and Tourism: A Review of Publications from 2005 to 2007. J. Travel Tour. Mark. 2009, 26, 599-623.

48. Maervoet, J.; Souffriau, W.; Vansteenwegen, P.; Vaden Berghea, G.; van Oudheusden, D. Tourist Decision Support for Mobile Navigation Systems: A Demonstration. Appl. Artif. Intell. 2008, 22, 964-985. 
49. Maruyama, A.; Shibata, N.; Murata, Y.; Yasumoto, K.; Ito, M. P-tour: A personal navigation system for tourism. In Proceedings of the 11th World Congress on ITS, Nagoya, Japan, 17-22 October 2004; pp. 18-21.

50. Sinleunam, P.; Poolsawad, K.; Tritilanunt, S. A Web-based decision support system for eco-tourism planning: A case study of national park in Chiangmai province. In Proceedings of the Computer Science and Software Engineering (JCSSE) Eighth International Joint Conference, Nakhon Pathom, Thailand, 11-13 May 2011; pp. 96-101.

51. Reid, R.D.; Bojanic, D.C. Hospitality Marketing Management; John Wiley and Sons: Hoboken, NJ, USA, 2009.

52. Del Bianco, P. The Spirit of Place between the Intangible and the Tangible. In Proceedings of the 16th General Assembly and International Scientific Symposium, Quebec City, QC, Canada, 29 September-4 October 2008.

53. Pike, S.; Ryan, C. Destination positioning analysis through a comparison of cognitive, affective and conative perceptions. J. Travel Res. 2004, 42, 333-342.

54. Maslow, A.H. Motivation and Personality, 3rd ed.; Frager, R., Fadiman, J., McReynolds, C., Cox, R., Eds.; Addison Wesley: Upper Saddle River, NJ, USA, 1987.

55. Garau, C. Perspectives on Cultural and Sustainable Rural Tourism in a Smart Region: The Case Study of Marmilla in Sardinia (Italy). Sustainability 2015, 7, 6412-6434.

56. Pike, S. Destination Marketing Organizations; Elsevier: Amsterdam, The Netherland, 2004.

57. European Commission. Consolidated Versions of the Treaty on European Union and the Treaty on the Functioning of the European Union. Available online: http://eur-lex.europa.eu/legal-content/ EN/TXT/?uri=celex:12012E/TXT (accessed on 18 September 2015).

58. Ali, A.; Frew, A.J. Information and Communication Technologies for Sustainable Tourism; Routledge: London, UK, 2013.

(C) 2015 by the authors; licensee MDPI, Basel, Switzerland. This article is an open access article distributed under the terms and conditions of the Creative Commons Attribution license (http://creativecommons.org/licenses/by/4.0/). 